Vol.5 No.2

\title{
ANALISIS LAPORAN KEUANGAN TERHADAP PROFITABILITAS DENGAN DEBT TO EQUITY RATIO SEBAGAI VARIABEL MODERASI PADA PERUSAHAAN MANUFAKTUR YANG TERDAFTAR DI BURSA EFEK INDONESIA PERIODE 2011 - 2015
}

Sauh Hwee Teng, Enda Noviyanti Simorangkir

Universitas Prima Medan

A R T I C LE INFO

Keywords : Cash Turnover, Account Receivable Turnover, Liquidity, Profitability,

Kata Kunci : Perputaran Kas, Perputaran Piutang, Likuiditas, Profitabilitas

Corresponding author : Sauh Hwee Teng tengsauhhwee@ unprimdn.ac.id
Abstract : Cash turnover is the level of sufficiency of working capital and cash in paying bills (debt) and costs related to the sale. Accounts receivable turnover showed how quickly companies charge his credit as measured by the length of time accounts receivable billed. Accounts receivable turnover is derived from the length of the receivable is converted into cash, receivables arising due to the sale of goods or services in credit. Liquidity shows the ability of a company to meet its financial obligations at the time charged. The purpose of this research was to prove there is whether or not the influence of rotation of cash, accounts receivable turnover, liquidity and profitability of the company against property and real estate in BEI. The population in this research is the entire company property and real estate by taking the sample criteria amounted to 50 company property and real estate. Data collection technique using the library and documentation studies through the medium of the internet site www.idx.co.id. The research on analysis techniques using multiple linear regression, $t$-test and $F$-test.

Abstrak :Perputaran kas merupakan tingkat kecukupan modal kerja serta kas dalam membayar tagihan (hutang) dan biaya-biaya yang berkaitan dengan penjualan. Perputaran piutang menunjukkan seberapa cepat perusahaan menagih kreditnya yang diukur oleh lamanya waktu piutang ditagih. Perputaran piutang berasal dari lamanya piutang diubah menjadi kas, piutang timbul karena adanya transaksi penjualan barang atau jasa secara kredit. Likuiditas menunjukkan kemampuan suatu perusahaan untuk memenuhi kewajiban keuangannya pada saat ditagih. Tujuan penelitian ini adalah untuk membuktikan ada tidaknya pengaruh perputaran kas, perputaran piutang, dan likuiditas terhadap profitabilitas pada perusahaan property dan real estate di BEI. Populasi dalam penelitian ini adalah seluruh perusahaan property dan real estate dengan mengambil kriteria sampel berjumlah 50 perusahaan property dan real estate. Teknik pengumpulan data menggunakan studi pustaka dan dokumentasi melalui media internet dengan situs www.idx.co.id. Teknik analisis pada penelitian ini menggunakan regresi linear berganda, uji $\mathrm{F}$ dan uji t. 


\section{PENDAHULUAN}

\section{Latar Belakang}

Perkembangan perusahaan di Indonesia saat ini sangat pesat sehingga persaingan yang terjadi cukup tajam dimana masing-masing perusahaan berupaya mempertahankan kelangsungan hidupnya dengan melakukan penjualan. Perusahaan yang ada di Indonesia ada perusahaan yang go public dan perusahaan non go public. Perusahaan go public adalah perusahaan yang tercatat di Bursa Efek Indonesia. Salah satu perusahaan go public yang terdaftar di Bursa Efek Indonesia adalah perusahaan manufaktur. Kelangsungan hidup perusahaan dapat dilihat pada laporan keuangan.

Perusahaan manufaktur merupakan sektor yang dominan dalam Bursa Efek Indonesia. Hal ini terlihat dari sirkulasi dan aktivitasnya yang cukup aktif di Bursa Efek Indonesia. Perusahaan manufaktur merupakan perusahaan yang memberdayakan mesin, peralatan, dan tenaga kerja untuk mengolah barang mentah atau yang setengah jadi menjadi barang yang jadi yang siap untuk dipasarkan ataupun dikonsumsi. Dalam hal pengadaan "mesin, peralatan, dan tenaga kerja", modal yang dibutuhkan tidaklah kecil. Oleh karena itu, suatu hal yang esensial bagi pemilik perusahaan untuk memperoleh modal diluar asset miliknya sendiri untuk mendukung operasional perusahaannya.

Berdasarkan uraian di atas, hal inilah yang membuat peneliti tertarik untuk melakukan penelitian dengan judul "Analisis Laporan Keuangan Terhadap Profitabilitas dengan Debt To Equity Ratio sebagai Variabel Moderasi Pada Perusahaan Manufaktur yang Terdaftar di Bursa Efek Indonesia Periode 2011 - 2015”.

\section{Tujuan Penelitian}

Tujuan dari penelitian ini adalah : "Untuk mengetahui bagaimana pengaruh current ratio, perputaran kas, modal kerja, dan debt ratio akan mempengaruhi return on assets dengan debt to equity ratio sebagai variabel moderating pada perusahaan manufaktur yang terdaftar di Bursa Efek Indonesia periode 2011-2015 ”.

\section{TINJAUAN PUSTAKA}

\section{Current Ratio}

Current ratio merupakan bagian dari likuiditas sehingga peneliti dapat memberikan pengertian dari likuiditas.

Menurut Murhadi (2013:57), Rasio likuiditas adalah rasio yang menunjukkan kemampuan perusahaan dalam memenuhi liabilitas jangka pendeknya.

Menurut Hantono ( 2017 : 9), current ratio menunjukkan jumlah kewajiban lancar yang dijamin pembayarannya oleh aktiva lancar. Semakin tinggi hasil perbandingan aktiva lancar dengan kewajiban lancar Rumus :

\section{Perputaran Kas}

$$
\text { Current Ratio }=\frac{\text { Aktiva Lancar }}{\text { Utang Lancar }}
$$

Menurut Riyanto (2015 : 95), perputaran kas adalah perbandingan antara penjualan dengan jumlah kas ratarata.

Menurut Kasmir (2013: 141), rumus yang digunakan untuk mencari rasio perputaran kas adalah sebagai berikut :

\section{Modal Kerja}

$$
\text { Perputaran Kas }=\frac{\text { Penjualan Bersih }}{\text { Modal Kerja Bersih }}
$$

Menurut Fahmi (2014 : 69), modal kerja adalah investasi sebuah perusahaan pada aktiva-aktiva jangka pendek-kas, sekuritas, persediaan dan piutang.

Menurut Kamaludin (2012 : 121), modal kerja bersih (net working capital) adalah jumlah harta lancar dikurangi hutang lancar. 


\section{Debt Ratio}

Menurut Fahmi (2014 : 72), dimana rasio ini disebut juga sebagai rasio untuk melihat perbandingan utang perusahaan yaitu diperoleh dari perbandingan total utang dibagi dengan total aset.

Menurut Kasmir (2014:156), debt to asset ratio (Debt Ratio) merupakan rasio utang yang digunakan untuk mengukur perbandingan antara total utang dengan total aktiva.

Rumus :

\section{Debt to Equity Ratio (DER)}

$$
\text { Debt to Asset Ratio }=\frac{\text { Total Debt }}{\text { Total Assets }}
$$
ekuitas.

Menurut Kasmir (2012 : 157), debt to equity ratio merupakan rasio yang digunakan untuk menilai utang dan

Menurut Hantono (2017 : 12), Debt to Equity (DER) adalah rasio yang menunjukkan sejauh mana modal sendiri menjamin seluruh utang. Rasio ini dicari dengan cara membandingkan antara seluruh utang lancar dengan seluruh utang ekuitas.

\section{Return on Assets (ROA)}

$$
\text { Debt to Equity Ratio }=\frac{\text { Total Utang }}{\text { Total Ekuitas }}
$$

Menurut Sitanggang (2012 :27),return on assets yaitu rasio yang mengukur kemampuan perusahaan dalam memperoleh laba bersih dari jumlah dana uang diinvestasikan perusahaan.

$$
\text { Return on Asset }=\frac{\text { Laba Bersih }}{\text { Total Aset }}
$$

\section{Penelitian Terdahulu}

Agus Wibowo (2012) melakukan penelitian dengan judul "Efisiensi Modal Kerja, Likuiditas, dan Leverage Terhadap Profitabilitas Pada Perusahaan Manufaktur di BEI". Hasil penelitiannya menunjukkan bahwa Secara Simultan Working Capital Turnover, Current Ratio, dept to total asset berpengaruh signifikan terhadap profitabilitas.Secara Parsial, modal kerja berpengaruh signifikan terhadap profitabilitas.

Anojan Vickneswaran (2014) melakukan penelitian dengan judul" Liquidity Management, Capital Structure and Their Impact on Profitability: A Study of Selected Listed Beverage, Food and Tobacco Firms in Colombo Stock Exchange (CSE) in Sri Lanka". Hasil penelitiannya menunjukkan bahwa liquidity management is negatively correlated with firm's profitability as well capital structure is negatively correlated with firm's profitability.

Septy Wulan Sari (2017) melakukan penelitian dengan judul "Pengaruh Struktur Modal, Likuiditas Terhadap Profitabilitas Perusahaan Makanan dan Minuman di BEI “. Hasil penelitiannya menunjukkan bahwa secara simultan Struktur modal dan likuiditas berpengaruh terhadap profitabilitas dan secara parsial, struktur modal berpengaruh positif dan tidak signifikan dan likuiditas berpengaruh positif dan signifikan terhadap profitabilitas.

\section{Kerangka Konseptual dan Hipotesis}

Berdasarkan latar belakang dan tinjauan teoritas yang telah dikemukakan sebelumnya, maka kerangka konseptual dapat digambarkan sebagai berikut : 


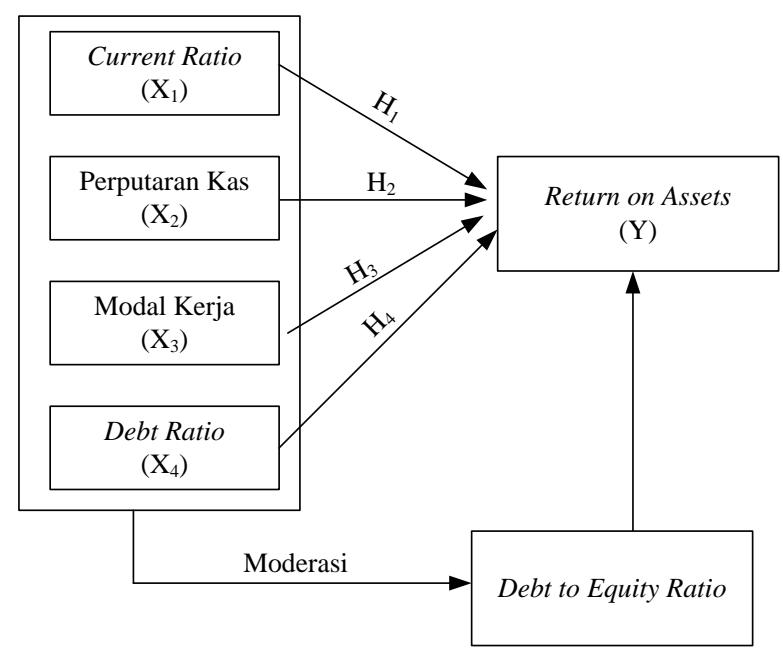

Gambar 1. Kerangka konseptual

\section{METODE PENELITIAN}

\section{Jenis dan Sifat Penelitian \\ Jenis Data}

Jenis data yang digunakan dalam penelitian ini adalah data sekunder, yaitu data yang tidak secara langsung diambil dari perusahaan ataupun data yang diperoleh dari pihak lain diluar perusahaan. Menurut Sugiyono (2012:376), data sekunder adalah sumber yang tidak langsung memberikan data kepada pengumpul data.

Data yang dipakai adalah data yang diambil dari website www.idx.co.id dan dari berbagai referensi yang berkaitan dengan data-data yang dipakai dalam penelitian ini.

\section{Pendekatan Penelitian}

Pendekatan penelitian ini dilakukan dengan penelitian kuantitatif. Menurut Sugiyono (2012:12), penelitian kuantitatif adalah penelitian yang berupa angka-angka dan analisis menggunakan statistik.

Data yang diambil pada penelitian ini berupa data current ratio, perputaran kas, modal kerja, debt ratio, return on assets dan debt to equity ratio pada perusahaan manufaktur yang terdaftar di Bursa Efek Indonesia periode 2011-2015.

Jenis penelitian yang digunakan adalah penelitian deskriptif. Menurut Sanusi (2012:13), desain penelitian deskriptif adalah desain penelitian yang disusun dalam rangka memberikan gambaran secara sistematis tentang informasi ilmiah yang berasal dari subjek atau objek penelitian. Penelitian deskriptif berfokus pada penjelasan sistematis tentang fakta yang diperoleh saat penelitian dilakukan.

Penelitian ini bersifat korelasional, yakni menjelaskan hubungan antar variabel penelitian. Penelitian ini dengan menggunakan data sekunder, yaitu berupa dokumen-dokumen dan laporan keuangan perusahaan manufaktur yang berhubungan dengan penelitian ini. Data tersebut diperoleh dari website Bursa Efek Indonesia Indonesia yang berasal dari laporan keuangan tahunan yang menjadi sampel dengan periode 2011-2015 yang di download dari website resmi Bursa Efek Indonesia yaitu www.idx.co.id.

\section{Populasi dan Sampel}

Menurut Noor (2011), populasi merupakan elemen/anggota dari suatu wilayah yang menjadi sasaran penelitian atau merupakan keseluruhan (niversum). Populasi penelitian ini adalah seluruh perusahaan manufaktur yang terdaftar di Bursa Efek Indonesia periode 2011 sampai dengan periode 2015, dengan teknik pengambilan sampel penelitian dosen pemula ini adalah: 
1. Perusahaan manufaktur yang terdaftar di Bursa Efek Indonesia 2011 sampai dengan 2015.

2. Perusahaan manufaktur yang menghasil keuntungan atau memperoleh keuntungan periode 2011 sampai dengan 2015.

3. Perusahaan manufaktur yang mengalami kerugian periode 2011 sampai dengan 2015.

Pada penelitian ini peneliti akan menggunakan populasi pada perusahaan manufaktur yang terdaftar di Bursa Efek Indonesia periode 2011-2015.

Menurut Sugiyono (2012:116), sampel adalah bagian dari jumlah dan karakteristik yang dimiliki oleh populasi tersebut. Dalam penelitian ini peneliti menggunakan teknik purposive sampling. Menurut Sugiyono (2012:122), teknik purposive sampling yaitu teknik penentuan sampel dengan pertimbangan tertentu.

\section{Teknik Pengumpulan Data}

Teknik pengumpulan data penelitian ini dengan menggunakan studi dokumentasi, yaitu dengan cara mendownload laporan-laporan keuangan perusahan yang berada di Bursa Efek Indonesia yang menjadi sampel penelitian.

Teknik Analisis Data

Adapun langkah-langkah yang dilakukan oleh peneliti dalam menganalisa data adalah sebagai berikut :

\section{Uji Asumsi Klasik}

Uji asumsi klasik merupakan syarat terpenting dalam analisis regresi, maka sebelum dilakukannya analisis regresi khususnya regresi linier berganda maka terlebih dahulu dilakukan uji asumsi klasik yang terdiri dari:

\section{Uji Normalitas}

Uji Normalitas dilakukan dengan tujuan untuk menguji apakah dalam model regresi, variabel penganggu atau residual memiliki distribusi normal (Ghozali, 2013 : 160). Ada dua teknik untuk mendeteksi apakah data berdistribusi normal atau tidak yaitu dengan menggunakan analisis grafik (scatterplot), dan analisis statistika (Kolmogrov-Smirnov).

\section{Uji Heterokedastisitas}

Uji heterokedastisitas bertujuan untuk menguji apakah dalam model regresu terjadi ketidaksamaan variance dari residual satu pengamatan kepengamatan laiinya (Ghozali,2013:139). Untuk melihat atau mendektesi terjadi heterokedastisitas dalam penelitian ini, peneliti menggunakan grafik scatterplot, dan uji Glejser.

\section{Uji Multikolinieritas}

Menurut Ghozali (2013:105), Uji Multikolinieritas bertujuan untuk menguji apakah dalam model regresi ditemukan adanya korelasi antar variabel bebas. Untuk mendeteksi terjadinya multikolinieritas yaitu dapat dilakukan dengan melihat tolerance dan variance inflation factor, dengan asumsi yakni:

- $\quad$ Apabila tolerance $>0,1$ dan VIF $<10$, maka tidak terjadi gejala multikolinieritas

- $\quad$ Apabila tolerance $<0,1$ dan VIF $>10$, maka terjadi gejala multikolinieritas.

\section{Uji Autokorelasi}

Menurut Ghozali (2013:110), Uji autukorelasi bertujuan untuk menguji apakah dalam model regresi linier berganda terjadi korelasi antara kesalahan penganggu pada periode $t$ dengan kesalahan penganggu pada periode $t-1$ sebelumnya. Uji autokorelasi dapat dilakukan dengan melihat nilai Durbin-Watson (DW),

Setelah terlewati uji asumsi klasik, maka peneliti melakukan uji regresi linier berganda yang terdiri dari koefisien determinasi $\left(\mathrm{R}^{2}\right)$, uji secara bersama-sama (Uji-F), uji secara individu (Uji-t) yaitu:

1. Koefisien Determinasi $\left(\mathrm{R}^{2}\right)$

Koefisien determinasi berfugsi untuk melihat sejauhmana kemampuan model dalam menjelaskan variabel dependen.

2. Uji Secara Bersama-sama (Uji-F)

Uji secara bersama-sama (uji-F) merupakan untuk menguji apakah current ratio, perputaran kas, modal 
kerja, debt ratio, return on assets dan debt to equity ratio pada perusahaan manufaktur yang terdaftar di Bursa Efek Indonesia periode 2011-2015, dengan rumusan hipotesis sebagai berikut:

a. $\mathrm{H}_{0}: \mathrm{b}_{1}, \mathrm{~b}_{2}, \mathrm{~b}_{3}, \mathrm{~b}_{4}=0$ (laporan keuangan, debt to equity ratio sebagai variabel moderasi tidak berpengaruh secara bersama-sama terhadap profitabilitas di Bursa Efek Indonesia).

b. $\mathrm{H}_{1}: \mathrm{b}_{1}, \mathrm{~b}_{2}, \mathrm{~b}_{3}, \mathrm{~b}_{4} \neq 0$ (laporan keuangan, debt to equity ratio sebagai variabel moderasi berpengaruh secara bersama-sama terhadap profitabilitas di Bursa Efek Indonesia).

Dengan kriteria keputusan pada uji-F adalah:

a. $\quad \mathrm{F}_{\text {hitung }} \leq \mathrm{F}_{\text {tabel }}$ maka $\mathrm{H}_{0}$ diterima dan $\mathrm{H}_{1}$ ditolak pada alpha $5 \%$.

b. $\mathrm{F}_{\text {hitung }}>\mathrm{F}_{\text {tabel }}$ maka $\mathrm{H}_{0}$ ditolak dan $\mathrm{H}_{1}$ diterima pada alpha $5 \%$.

3. Uji Secara Individu (Uji-t)

Uji secara individu atau secara parsial merupakan untuk menguji apakah laporan keuangan, debt to equity ratio sebagai variabel moderasi berpengaruh secara individu terhadap profitabilitas di Bursa Efek Indonesia, dengan rumusan hipotesis sebagai berikut:

a. $\quad \mathrm{H}_{0}: \mathrm{b}_{1}, \mathrm{~b}_{2}, \mathrm{~b}_{3}, \mathrm{~b}_{4}=0$ (laporan keuangan, debt to equity ratio sebagai variabel moderasi tidak berpengaruh secara parsial terhadap profitabilitas di Bursa Efek Indonesia).

b. $\mathrm{H}_{1}: \mathrm{b}_{1}, \mathrm{~b}_{2}, \mathrm{~b}_{3}, \mathrm{~b}_{4} \neq 0$ (laporan keuangan, debt to equity ratio sebagai variabel moderasi berpengaruh secara parsial terhadap profitabilitas di Bursa Efek Indonesia).

Dengan kriteria pengujian uji-t adalah:

a. $\quad$ Jika $\mathrm{t}_{\text {hitung }} \leq \mathrm{t}_{\text {tabel }}$ maka $\mathrm{H}_{0}$ diterima dan $\mathrm{H}_{1}$ ditolak pada alpha $5 \%$.

b. Jika $\mathrm{t}_{\text {hitung }}>\mathrm{t}_{\text {tabel }}$ maka $\mathrm{H}_{0}$ ditolak dan $\mathrm{H}_{1}$ diterima pada alpha $5 \%$.

\section{HASIL PENELITIAN DAN PEMBAHASAN}

\section{Hasil Penelitian}

Pengujian variabel current ratio, Perputaran Kas, Modal Kerja, Debt to Equity Ratio Terhadap Return on Assets.

\section{Uji Normalitas}

Tabel 1. Uji Run

\begin{tabular}{|c|c|}
\hline \multicolumn{2}{|c|}{ Runs Test } \\
\hline & $\begin{array}{l}\text { Unstandardiz } \\
\text { ed Residual }\end{array}$ \\
\hline Test Value ${ }^{a}$ & -.27069 \\
\hline Cases < Test Value & 75 \\
\hline Cases $>=$ Test Value & 76 \\
\hline Total Cases & 151 \\
\hline Number of Runs & 69 \\
\hline$z$ & -1.224 \\
\hline Asymp. Sig. (2-tailed) & .221 \\
\hline
\end{tabular}

a. Median

Berdasarkan pada tabel 1 bahwa dapat dilihat nilai Asympg.Sig (2-tailed) di atas 0,05 yakni 0.112, Hal ini menunjukkan bahwa data berdistribusi normal. 


\section{Uji Heterokedastisitas}

\section{Tabel 2. Uji Glejser}

\begin{tabular}{|c|c|c|c|c|c|c|}
\hline \multicolumn{7}{|c|}{ Coefficients $^{a}$} \\
\hline \multirow[b]{2}{*}{ Model } & & \multicolumn{2}{|c|}{ Unstandardized Coefficients } & \multirow{2}{*}{$\begin{array}{c}\text { Standardized } \\
\text { Coefficients } \\
\text { Beta }\end{array}$} & \multirow[b]{2}{*}{$t$} & \multirow[b]{2}{*}{ Sig. } \\
\hline & & B & Std. Error & & & \\
\hline \multirow[t]{5}{*}{1} & (Constant) & .037 & .042 & & .872 & .385 \\
\hline & $\mathrm{CR}$ & .002 & .008 & .021 & .226 & .822 \\
\hline & PK & .003 & .001 & .415 & 5.447 & .000 \\
\hline & MK & $-2.844 E-15$ & .000 & -.015 & -.163 & .871 \\
\hline & DR & .024 & .056 & .033 & .433 & .665 \\
\hline
\end{tabular}

a. Dependent Variable: res2

Berdasarkan pada tabel .2 menunjukkan nilai signifikannya salah satu variabelnya menunjukkan di bawah 0.05 sehingga terjadi heteroskedastisitas dalam model regresi penelitian ini setelah peneliti membuang variabel yang penganggu yang menyebabkan terjadinya gejala heteroskedastisitas yaitu dengan membuang variabel perputaran kas. Berikut ini hasil uji heteroskedastisitas setelah variabel penganggunya dibuang adalah sebagai berikut:

\section{Tabel 3. Uji Glejser}

\begin{tabular}{|c|c|c|c|c|c|c|}
\hline \multicolumn{7}{|c|}{ Coefficients $^{a}$} \\
\hline & & \multicolumn{2}{|c|}{ Unstandardized Coefficients } & \multirow{2}{*}{$\begin{array}{c}\text { Standardized } \\
\text { Coefficients } \\
\text { Beta }\end{array}$} & \multirow[b]{2}{*}{$t$} & \multirow[b]{2}{*}{ Sig. } \\
\hline \multicolumn{2}{|c|}{ Model } & B & Std. Error & & & \\
\hline \multirow[t]{4}{*}{1} & (Constant) & .088 & .045 & & 1.954 & .053 \\
\hline & $\mathrm{CR}$ & -.002 & .009 & -.021 & -.211 & .833 \\
\hline & MK & $-7.112 \mathrm{E}-15$ & .000 & -.037 & -.372 & .710 \\
\hline & DR & .045 & .061 & .061 & .729 & .467 \\
\hline
\end{tabular}

a. Dependent Variable: res2

Berdasarkan pada tabel .3 menunjukkan nilai signifikannya di atas 0.05 sehingga tidak terjadi heteroskedastisitas dalam model regresi penelitian ini.

\section{Uji Multikolinieritas}

\section{Tabel 4. Uji Multikolinieritas}

\begin{tabular}{|c|c|c|c|}
\hline \multirow{2}{*}{\multicolumn{2}{|c|}{ Model }} & \multicolumn{2}{|c|}{ Collinearity Statistics } \\
\hline & & Tolerance & VIF \\
\hline \multirow[t]{4}{*}{1} & CR & .658 & 1.519 \\
\hline & PK & .973 & 1.027 \\
\hline & MK & .670 & 1.493 \\
\hline & DR & .973 & 1.028 \\
\hline
\end{tabular}

a. Dependent Variable: ROA

Berdasarkan output di atas dapat diketahui bahwa nilai tolerance lebih besar dari 0,1 dan VIF lebih kecil dari 10 maka artinya tidak terjadi multikolinieritas. 


\section{Uji Autokorelasi}

\section{Tabel 5. Uji Autokorelasi}

\begin{tabular}{|c|c|c|c|c|c|}
\hline \multicolumn{6}{|c|}{ Model Summary } \\
\hline Model & $\mathrm{R}$ & R Square & $\begin{array}{l}\text { Adjusted R } \\
\text { Square }\end{array}$ & $\begin{array}{l}\text { Std. Error of } \\
\text { the Estimate }\end{array}$ & $\begin{array}{l}\text { Durbin- } \\
\text { Watson }\end{array}$ \\
\hline 1 & $.453^{a}$ & .205 & .183 & .93792 & 2.449 \\
\hline
\end{tabular}

Berdasarkan pada nilai DW sebesar 2.449, bahwa dapat dilihat tidak terjadi gejala Autokorelasi pada penelitian ini

Setelah terlewati uji asumsi klasik, maka peneliti melakukan uji regresi linier berganda yang terdiri dari koefisien determinasi $\left(\mathrm{R}^{2}\right)$, uji secara bersama-sama (Uji-F), uji secara individu (Uji-t) yaitu:

Koefisien Determinasi $\left(\mathbf{R}^{2}\right)$

\section{Tabel 6. Koefisien Determinasi}

\begin{tabular}{|c|c|c|c|c|c|}
\hline \multicolumn{6}{|c|}{ Model Summary } \\
\hline Model & $R$ & R Square & $\begin{array}{l}\text { Adjusted R } \\
\text { Square }\end{array}$ & $\begin{array}{l}\text { Std. Error of } \\
\text { the Estimate }\end{array}$ & $\begin{array}{l}\text { Durbin- } \\
\text { Watson }\end{array}$ \\
\hline 1 & $.453^{\mathrm{a}}$ & .205 & .183 & .93792 & 2.449 \\
\hline
\end{tabular}

Berdasarkan pada tabel 6 nilai R-Square sebesar 0,205 atau sebesar $20.5 \%$. Hal ini menunjukkan bahwa debt ratio, modal kerja, perputaran kas, current ratio hanya dapat menjelaskan variabel return on assets sebesar $20.5 \%$, sedangkan sisanya di luar variabel penelitian ini.

\section{Uji Secara Bersama-sama (Uji-F)}

\section{Tabel 7.Uji F}

\begin{tabular}{|c|c|c|c|c|c|c|}
\hline \multicolumn{7}{|c|}{ ANOVA $^{a}$} \\
\hline & Model & $\begin{array}{l}\text { Sum of } \\
\text { Squares }\end{array}$ & df & Mean Square & $\mathrm{F}$ & Sig. \\
\hline \multirow[t]{3}{*}{1} & Regression & 32.935 & 4 & 8.234 & 9.360 & $.000^{\mathrm{b}}$ \\
\hline & Residual & 127.557 & 145 & .880 & & \\
\hline & Total & 160.492 & 149 & & & \\
\hline
\end{tabular}

Berdasarkan pada tabel 5.7 bahwa debt ratio, modal kerja, perputaran kas, current ratio berpengaruh secara bersama-sama terhadap return on assets di Bursa Efek Indonesia dengan nilai signifikansi di bawah 0,05\%.

\section{Uji Secara Individu (Uji-t)}

\section{Tabel 8.Uji t}

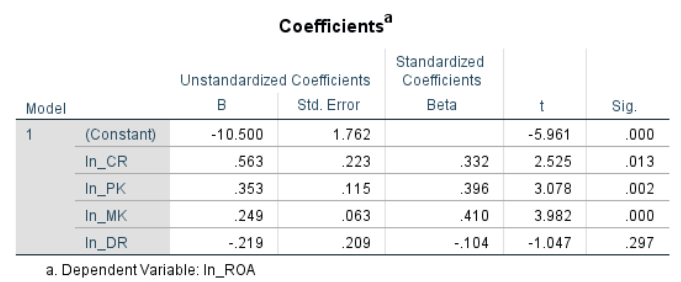

Berdasarkan pada Tabel 8 bahwa hasil uji t adalah sebagai berikut:

1. Current Ratio berpengaruh secara individu terhadap return on assets di Bursa Efek Indonesia. 
Current ratio memiliki nilai signifikansi sebesar 2.525 dengan nilai $t_{\text {tabel }}$ sebesar 1.975 dengan demikian nilai $\mathrm{t}_{\text {hitung }}>\mathrm{t}_{\text {tabel }}$ maka dapat dikatakan variabel current ratio berpengaruh terhadap return on assets.

2. Perputaran Kas berpengaruh secara individu terhadap return on assets di Bursa Efek Indonesia.

Perputaran Kas memiliki nilai signifikansi sebesar 3.078 dengan nilai $t_{\text {tabel }}$ sebesar 1.975 dengan demikian nilai $\mathrm{t}_{\text {hitung }}>\mathrm{t}_{\text {tabel }}$ maka dapat dikatakan variabel perputaran kas berpengaruh terhadap return on assets.

3. Modal Kerja berpengaruh secara individu terhadap return on assets di Bursa Efek Indonesia.

Modal Kerja memiliki nilai signifikansi sebesar 3.982 dengan nilai $t_{\text {tabel }}$ sebesar 1.975 dengan demikian nilai $t$ hitung $>\mathrm{t}_{\text {tabel }}$ maka dapat dikatakan variabel modal kerja berpengaruh terhadap return on assets.

4. Debt Ratio berpengaruh secara individu terhadap return on assets di Bursa Efek Indonesia.

Debt Ratio memiliki nilai signifikansi sebesar - 1.047 dengan nilai $t_{\text {tabel }}$ sebesar 1.975 dengan demikian nilai $\mathrm{t}_{\text {hitung }}<\mathrm{t}_{\text {tabel }}$ maka dapat dikatakan variabel debt ratio tidak berpengaruh terhadap return on assets.

Pengujian variabel current ratio, Perputaran Kas, Modal Kerja, Debt Ratio Terhadap Return on Assets dengan Debt to Equity Ratio sebagai variabel moderasi

Uji Normalitas

Tabel 9. Uji Run

\begin{tabular}{lr}
\multicolumn{2}{c}{ Runs Test } \\
& $\begin{array}{c}\text { Unstandardized } \\
\text { Residual }\end{array}$ \\
\hline Test Value $^{\text {a }}$ & -.02183 \\
\hline Cases < Test Value & 75 \\
\hline Cases >= Test Value & 76 \\
\hline Total Cases & 151 \\
\hline Number of Runs & 82 \\
\hline Z & .899 \\
\hline Asymp. Sig. (2-tailed) & .369 \\
\hline \multicolumn{2}{c}{ a. Median }
\end{tabular}

Berdasarkan pada tabel 5.9 bahwa dapat dilihat nilai Asympg.Sig (2-tailed) di atas 0,05 yakni 0.369, Hal ini menunjukkan bahwa data berdistribusi normal.

\section{Uji Heterokedastisitas}

Uji heterokedastisitas bertujuan untuk menguji apakah dalam model regresi terjadi ketidaksamaan variance dari residual satu pengamatan kepengamatan lainnya(Ghozali,2013:139). Untuk melihat atau mendeteksi terjadi heterokedastisitas dalam penelitian ini, peneliti menggunakan grafik scatterplot, Berikut ini hasil uji heterokedastisitas dengan menggunakan grafik scatterplot adalah:

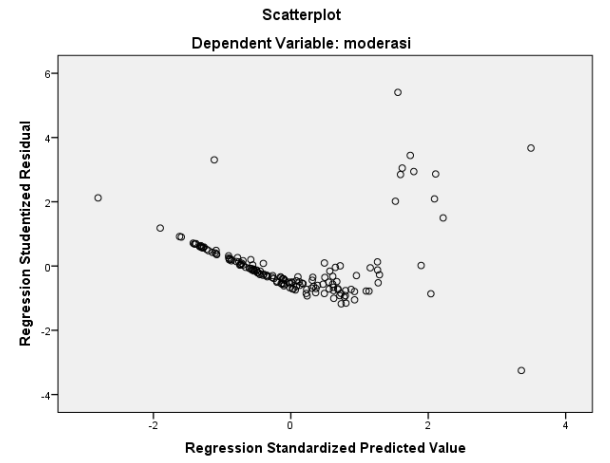

Gambar 2. Grafik Scatterplot

Dari gambar di atas memperlihatkan bahwa titik-titik menyebar secara acak di atas maupun di bawah angka 
0 dan pada sumbu Y. Dengan demikian dapat disimpulkan bahwa tidak terjadi heteroskedastisitas pada model sehingga model penelitian ini layak dipakai.

\section{Uji Multikolinieritas}

Tabel 10.Uji Multikolinieritas

\begin{tabular}{|c|c|c|c|}
\hline \multicolumn{4}{|c|}{ Coefficients $^{a}$} \\
\hline & & \multicolumn{2}{|c|}{ Collinearity Statistics } \\
\hline Model & & Tolerance & VIF \\
\hline \multirow[t]{4}{*}{1} & In_CR & .319 & 3.132 \\
\hline & In_PK & .330 & 3.026 \\
\hline & In_MK & .517 & 1.932 \\
\hline & In_DR & .560 & 1.786 \\
\hline
\end{tabular}

a. Dependent Variable: moderasi

Berdasarkan output di atas dapat diketahui bahwa nilai tolerance lebih besar dari 0,1 dan VIF lebih kecil dari 10 maka artinya tidak terjadi multikolinieritas.

\section{Uji Autokorelasi}

\section{Tabel 11.Uji Autokorelasi}

\begin{tabular}{|c|c|c|c|c|c|}
\hline \multicolumn{6}{|c|}{ Model Summary } \\
\hline Model & $R$ & R Square & $\begin{array}{l}\text { Adjusted R } \\
\text { Square }\end{array}$ & $\begin{array}{l}\text { Std. Error of the } \\
\text { Estimate }\end{array}$ & $\begin{array}{l}\text { Durbin- } \\
\text { Watson }\end{array}$ \\
\hline 1 & $.705^{\mathrm{a}}$ & .497 & .483 & 374705901181.5 & 2.206 \\
\hline
\end{tabular}
ini

Berdasarkan pada nilai DW sebesar 2.206 bahwa dapat dilihat tidak terjadi gejala Autokorelasi pada penelitian

Setelah terlewati uji asumsi klasik, maka peneliti melakukan uji regresi linier berganda yang terdiri dari koefisien determinasi $\left(\mathrm{R}^{2}\right)$, uji secara bersama-sama (Uji-F), uji secara individu (Uji-t) yaitu:

\section{Koefisien Determinasi $\left(\mathbf{R}^{2}\right)$}

Tabel 12.Koefisien Determinasi

\begin{tabular}{|c|c|c|c|c|c|}
\hline \multicolumn{6}{|c|}{ Model Summary } \\
\hline Model & $\mathrm{R}$ & R Square & $\begin{array}{l}\text { Adjusted R } \\
\text { Square }\end{array}$ & $\begin{array}{l}\text { Std. Error of the } \\
\text { Estimate }\end{array}$ & $\begin{array}{l}\text { Durbin- } \\
\text { Watson }\end{array}$ \\
\hline 1 & $.705^{\mathrm{a}}$ & .497 & .483 & 374705901181.5 & 2.206 \\
\hline
\end{tabular}

Berdasarkan pada tabel 12 nilai R-Square sebesar 0.497 atau sebesar $49.7 \%$. Hal ini menunjukkan bahwa debt ratio, modal kerja, perputaran kas, current ratio hanya dapat menjelaskan variabel return on assets dengan variabel moderasi debt to equity ratio sebesar $49.7 \%$, sedangkan sisanya di luar variabel penelitian ini. 


\section{Uji Secara Bersama-sama (Uji-F)}

\section{Tabel 13. Uji F}

\begin{tabular}{|c|c|c|c|c|c|c|}
\hline \multicolumn{7}{|c|}{ ANOVA $^{a}$} \\
\hline Model & & $\begin{array}{l}\text { Sum of } \\
\text { Squares }\end{array}$ & df & Mean Square & $\mathrm{F}$ & Sig. \\
\hline \multirow[t]{3}{*}{1} & Regression & $2.023 E+25$ & 4 & 5058665486865780000000000 & 36.029 & $.000^{\mathrm{b}}$ \\
\hline & Residual & $2.050 \mathrm{E}+25$ & 146 & 1404045123802274400000000.0 & & \\
\hline & Total & $4.073 E+25$ & 150 & & & \\
\hline
\end{tabular}

a. Dependent Variable: moderasi

b. Predictors: (Constant), In_DR, In_MK, In_PK, In_CR

Berdasarkan pada tabel 13 bahwa debt ratio, modal kerja, perputaran kas, current ratio berpengaruh secara bersama-sama terhadap return on assets dengan variabel moderasi debt to equity ratio di Bursa Efek Indonesia dengan nilai signifikansi di bawah $0,05 \%$.

\section{Uji Secara Individu (Uji-t)}

\section{Tabel 14. Uji t}

\begin{tabular}{|c|c|c|c|c|c|c|}
\hline \multicolumn{7}{|c|}{ Coefficients $^{a}$} \\
\hline \multirow[b]{2}{*}{ Model } & & \multicolumn{2}{|c|}{ Unstandardized Coefficients } & \multirow{2}{*}{$\begin{array}{c}\text { Standardized } \\
\text { Coefficients } \\
\text { Beta }\end{array}$} & \multirow[b]{2}{*}{$\mathrm{t}$} & \multirow[b]{2}{*}{ Sig. } \\
\hline & & B & Std. Error & & & \\
\hline \multirow[t]{5}{*}{1} & (Constant) & -6153446732000.000 & 703351055700.000 & & -8.749 & .000 \\
\hline & In_CR & 428356745600.000 & 88702468810.000 & .502 & 4.829 & .000 \\
\hline & In_PK & 230497236200.000 & 45733280610.000 & .515 & 5.040 & .000 \\
\hline & In_MK & 232239009000.000 & 25001771980.000 & .758 & 9.289 & .000 \\
\hline & In_DR & 355074726800.000 & 83005794320.000 & .336 & 4.278 & .000 \\
\hline
\end{tabular}

\footnotetext{
a. Dependent Variable: moderasi
}

Berdasarkan pada tabel.14 bahwa hasil uji t adalah sebagai berikut:

1. Current Ratio berpengaruh secara individu terhadap return on assets dengan debt to equity ratio sebagai variabel moderasi.

Current ratio memiliki nilai signifikansi sebesar 4.829 dengan nilai $\mathrm{t}_{\text {tabel }}$ sebesar 1.975 dengan demikian nilai $\mathrm{t}_{\text {hitung }}>\mathrm{t}_{\text {tabel }}$ maka dapat dikatakan variabel current ratio berpengaruh terhadap return on assets debt to equity ratio sebagai variabel moderasi.

2. Perputaran Kas berpengaruh secara individu terhadap return on assets dengan debt to equity ratio sebagai variabel moderasi.

Perputaran Kas memiliki nilai signifikansi sebesar 5.040 dengan nilai $t_{\text {tabel }}$ sebesar 1.975 dengan demikian nilai $\mathrm{t}_{\text {hitung }}>\mathrm{t}$ tabel maka dapat dikatakan variabel perputaran kas berpengaruh terhadap return on assets dengan debt to equity ratio sebagai variabel moderasi.

3. Modal Kerja berpengaruh secara individu terhadap return on assets dengan debt to equity ratio sebagai variabel moderasi

Modal Kerja memiliki nilai signifikansi sebesar 9.289 dengan nilai $t_{\text {tabel }}$ sebesar 1.975 dengan demikian nilai $t$ hitung $>\mathrm{t}_{\text {tabel }}$ maka dapat dikatakan variabel modal kerja berpengaruh terhadap return on assets dengan debt to equity ratio sebagai variabel moderasi

4. Debt Ratio berpengaruh secara individu terhadap return on assets dengan debt to equity ratio sebagai variabel moderasi

Debt Ratio memiliki nilai signifikansi sebesar 4.278 dengan nilai $\mathrm{t}_{\text {tabel }}$ sebesar 1.975 dengan demikian nilai $\mathrm{t}$ hitung $>\mathrm{t}_{\text {tabel }}$ maka dapat dikatakan variabel debt ratio tidak berpengaruh terhadap return on assets dengan debt to equity ratio sebagai variabel moderasi. 


\section{Kesimpulan}

\section{PENUTUP}

Kesimpulan pada penelitian ini bahwa Current Ratio, Perputaran Kas, Modal Kerja, Debt Ratio berpengaruh secara bersama-sama terhadap Return on Assets di Bursa Efek Indonesia dan juga variabel current ratio, Perputaran Kas, Modal Kerja, Debt Ratio berpengaruh secara bersama-sama terhadap Return on Assets dengan Debt to Equity Ratio sebagai variabel moderasi, sedangkan secara individual debt ratio berpengaruh terhadap return on assets.

\section{Saran}

Saran-saran yang dapat dikemukakan peneliti berkaitan dengan hasil penelitian ini antara lain :

1. Bagi peneliti lain agar sampel penelitian menggunakan populasi yang lebih luas dan sampel yang lebih banyak sehingga hasil yang diperoleh lebih akurat dan tepat.

2. Bagi perusahaan agar manajemen tetap memperhatikan perputaran piutang dalam melaksanakan kegiatan operasionalnya karena variabel ini dapat mempengaruhi besarnya profitabilitas sebagai gambaran keuangan perusahaan.

3. Bagi Investor yang ingin melakukan investasi hendaknya melakukan penelitian lebih lanjut mengenai kinerja perusahaan yang menyangkut Current Ratio, Perputaran Kas, Modal Kerja, Debt Ratio, Return on Assets.

\section{DAFTAR PUSTAKA}

Anojan, Vickneswaran. 2014. Liquidity Management, Capital Structure and Their Impact on Profitability: A Study of Selected Listed Beverage, Food and Tobacco Firms in Colombo Stock Exchange (CSE) in Sri Lanka. International Journal of Finance and Accounting.

Fahmi, Irham. 2013. Pengantar Manajemen Keuangan. Cetakan Kedua. Bandung : Alfabeta.

Hantono. 2017. Konsep Analisa Laporan Keuangan dengan Pendekatan Rasio dan SPSS. Cetakan Pertama. Yogyakarta : Deepublish.

Hantono. 2017. Faktor Yang Mempengaruhi Profitabilitas Pada Perusahaan Property Dan Real Estate Yang Terdaftar Di Bei Periode 2012 -2015. Jurnal Manajemen Bisnis dan Inovasi. Vol. 5 No. 1. https://ejournal.unsrat.ac.id/index.php/jmbi/article/view/19147/18705

Kasmir, 2013. Analisis Laporan Keuangan, Jakarta : PT. Grafindo Persada.

Kesuma, Ali. 2009. Analisis Faktor yang Mempengaruhi Struktur Modal Serta Pengaruhnya Terhadap Harga Saham Perusahaan Real Estate yang Go Public di Bursa Efek Indonesia. Jurnal Manajemen dan Kewirausahaan . Vol.11, No. 1, Maret 2009: 38-45, Universitas Darwan Ali Sampit, Kalimantan.

Murhadi, Wenner R.2013. Analisis Laporan Keuangan Proyeksi dan Evaluasi Saham. Jakarta, Penerbit Salemba Empat.

Munawir. 2014. Analisa Laporan Keuangan. Yogyakarta : Liberty.

Riyanto, Bambang. 2015. Dasar-Dasar Pembelanjaan Perusahaan.Edisi 4. Yogyakarta : BPFE.

Silaen \& Widiyono. 2013. Metode Penelitian Sosial untuk Penulisan Skripsi dan Tesis. Jakarta: Penerbit In Media.

Sitanggang, J.P.2012. Manajemen Keuangan Perusahaan. Jakarta. Penerbit Mitra Wacana Media

Syafri, Sofyan. 2010. Analisis Kritis Atas Laporan Keuangan. Edisi Satu. Jakarta: Raja Grafindo Persada. 
Sari, Septy Wulan.2017. Pengaruh Struktur Modal, Likuiditas Terhadap Profitabilitas Perusahaan Makanan dan Minuman Di BEI. Jurnal Ilmu dan Riset Manajemen. Vol.6, No.6. STIESIA, Surabaya.

Tulung, Joy Elly, and Dendi Ramdani. 2018. Independence, Size and Performance of the Board: An Emerging Market Research. Corporate Ownership \& Control, Volume 15, Issue 2, Winter 2018.

Wibowo, Agus. 2012. Efisiensi Modal Kerja, Likuiditas, dan Leverage Terhadap Profitabilitas Pada Perusahaan Manufaktur di BEI. Jurnal Dinamika Manajemen. Fakultas Ekonomi, Universitas Negeri Semarang. 